\title{
LORD MORAN AND JAMES BOSWELL: THE TWO DIARISTS COMPARED AND CONTRASTED*
}

\author{
DOUGLAS HUBBLE
}

\section{INTRODUCTION}

I AM greatly honoured to have been invited to deliver the ninth Osler Lecture to the Faculty of the History of Medicine and Pharmacy. Sir William Osler was the great exemplar for the generation of physicians which preceded mine. The dominating interests in his life were medicine, English literature and medical history, and since my talk concerns, in varying degree, some aspects of these three subjects, I hope it may not be considered unsuitable for an Osler lecture.

I will begin with two recorded scraps of conversation. On 30 March 1792, Mrs. Piozzi said to Bishop Percy, talking of James Boswell, 'Let us be careful of our health, my Lord, or he will write our lives too'. On 3 August 1959, Harold Macmillan, then Prime Minister, asked at lunch at his home, Birch Grove, 'Who will be Winston's Boswell?' Lord Moran, who was a guest, did not declare himself but he later wrote down his account of the conversation.

Brendan Bracken had much earlier urged this Boswellian duty on Lord Moran who, as we now know, kept a diary from the day when he became Churchill's doctor on 24 May 1940. This diary was to provide the building stones for his book Winston Churchill. The Struggle for Survival. Moran's account of the first consultation at Admiralty House reveals something of the nature of his patient and of his own quality as an observer:

\footnotetext{
After what seemed quite a long time, he put down his papers and said impatiently: 'I don't know why they are making such a fuss. There's nothing wrong with me'.

He picked up his papers and resumed his reading. At last he pushed his bed-rest away and, throwing back the bed clothes said abruptly:

'I suffer from dyspepsia, and this is the treatment.'

With that he proceeded to demonstrate to me some breathing exercises. His big white belly was moving up and down when there was a knock on the door, and the P.M. grabbed at the sheet as Mrs. Hill came into the room.
}

Lord Moran was already a practised diarist. He formed the habit when he was a battalion medical officer in the First War and out of his diaries he constructed his book, The Anatomy of Courage. We may assume that he was not reluctant to travel through history with his great master, Winston Churchill, and we may justly add that his skill matched his unrivalled opportunity.

James Boswell wrote in 1783, 'I said to General Paoli it was wonderful how much Corsica had done for me, how far I had got in the world by having been there. I had

- The Osler Lecture, given before the Faculty of the History of Medicine and Pharmacy, 8 May 1968. 


\section{Douglas Hubble}

got upon a rock in Corsica and jumped into the middle of life'. Moran also might say that when he became Winston Churchill's physician he found himself in 'the middle of life'. Paoli, Boswell's hero, was a statesman and a general, who had saved his island people from the Genoese invaders, and the analogy with Winston Churchill is a close one. Although Boswell in his Journal of a Tour to Corsica had written a book which brought him immediate fame, he had not in 1768 perfected the Boswellian method of biography. The mature Boswell, the diarist and biographer, were not fully revealed till 1785 when he published the Journal of a Tour to the Hebrides, the prelude to the great Life of Samuel Johnson, published in 1791. It is to these two books we must look as we compare and contrast Moran's quality with Boswell's.

\section{RECORD KEEPING}

Both diarists employed a similar method of record keeping. Moran wrote: 'It became my custom as I drove away from No. 10 or Chequers or Chartwell to note, sometimes on the back of an envelope, anything that might help me to get to the bottom of his troubles. From these notes I wrote out the conversations with Winston the same night'. At some subsequent time Moran built his daily diaries into a continuous narrative filling in the gaps, adding retrospective comments and making his assessments of the parts played by the leading actors in the great events of the Second World War.

At the age of twenty-four, 24 October 1764, Boswell wrote: 'My method is to make a memorandum every night of what $I$ have seen during the day. By this means I have my materials always secured. Sometimes I am three, four, five days without journalizing. When I have time and spirits, I bring up this my Journal as well as I can in the hasty manner in which I write it'. He carried a notebook with him, but the satirical picture which Mrs. Thrale (later Mrs. Piozzi) drew of him 'sitting down steadily at the other end of the room to write at the moment what should either be said by Dr. Johnson or to him', is now discredited.

Both diarists had exceptional memories, and they trained themselves to retain their recollection of what had been done and said. Lord Moran was President of the Royal College of Physicians of London from 1941 to 1950 and he recited the obituaries of deceased Fellows-maybe up to 5,000 words-at the annual meeting of the College. The accuracy of his diary has been called in question, but there can be no denial of the quality of his remarkable memory.

On 21 March 1783, on an occasion when Johnson was 'talking triumphantly' Boswell exclaimed to Mrs. Thrale: 'O, for short-hand to take this down', and she rejoined: 'You'll carry it all in your head; a long head is as good as short-hand'. 'Boswell's remembered conversations', Pottle writes, 'are dramatic epitomes or miniatures. They probably do not preserve every word that was uttered; far from it. They probably do not preserve every topic that came up for discussion. But they invent no topics, and the important, the pivotal words, are ipsissima verba'. The same dramatic quality can be claimed for Moran's record. In quoting the following 'dramatic miniature' of Boswell's I choose this passage because it demonstrates the courage, laced with affection, with which Boswell handled Johnson. Johnson had been very rough with Boswell a few nights earlier: 


\section{Lord Moran and James Boswell}

On Friday, 8 May (1778) I dined with him at Mr. Langton's. I was reserved and silent, which I suppose he perceived, and might recollect the cause. After dinner, when Mr. Langton was called out of the room, and we were by ourselves, he drew his chair near to mine and said, in a tone of conciliating courtesy, 'Well, how have you done?'

Boswell: 'Sir, you have made me very uneasy by your behaviour to me when we were last at Sir Joshua Reynolds's. You know, my dear Sir, no man has a greater respect and affection for you, or would sooner go to the end of the world to serve you. Now to treat me so-.' He insisted that I had interrupted him, which I assured him was not the case; and proceeded-'But why treat me so before people who neither love you nor me?'

Johnson: 'Well, I am sorry for it. I'll make it up to you twenty different ways, as you please.' Boswell: 'I said today to Sir Joshua, when he observed that you tossed me sometimes-I don't care how often, or how high he tosses me, when only friends are present, for then I fall upon soft ground: but I do not like falling on stones, which is the case when enemies are present-I think this is a pretty good image, Sir.'

Johnson: 'Sir, it is one of the happiest I have ever heard.'

I shall later quote a passage from Moran demonstrating his courage in Churchillian debate, but meanwhile I make this quotation from The Struggle for Survival to illustrate Moran's 'dramatic epitomes'. The Conference at Yalta had ended on 11 February 1945.

This afternoon, at half-past four, as I was going for a walk, the P.M. swept into the house. 'We leave at five o'clock. Where's Tommy? Sawyers!' His voice rose, 'Sawyers! Where is everyone?"

Apparently there is bad weather approaching, and we must get off before it. It was half-past five when we left, and two hours later the car drew up on the jetty at Sebastopol. We were to dine and sleep in the Franconia. The P.M., who has been in a vile mood throughout the Conference, irritable and bad-tempered, is now in tearing spirits.

'I'm so relieved to get this bloody thing off.'

The bloody thing was the agreed communiqué.

'Anyway', he growled, 'that's done with and out of the way'. He is trying to forget that he has achieved little. He is playful, smiling, mischievous.

'Charles', he said, 'is silent, kindly and grave, but make no mistake, when the occasion comes, he lashes out like a horse.'

He put his hand affectionately on my knee.

'He demolished the President of the other College in The Times without any mercy.'

Twice he sang (very flat) snatches of old songs, 'The Soldiers of the Queen' and some ditty I had not heard before. This during dinner. Then he gurgled:

'Grand to get back to English fare after the sucking-pig and the cold fatty approaches to all their meals.'

The P.M. moves among words as a friend. His precision in their use is helpful at these Conferences, where sloppy thinking may lead to recrimination later. When he had given his blessing to the revision of the Montreaux Convention about the Dardanelles, and Stalin was in a relaxed mood, he gravely enquired of the President what he meant by 'Freedom from want.'

'I suppose the word "want" means privation and not desire.'

And when there was agreement about the joint communiqué, and everyone was smiling happily, he persuaded the President to cut out 'joint':

'The word "joint"', he said, 'means to me the Sunday family roast of mutton.'

\section{THE MOTIVATION AND EQUIPMENT OF THE DIARIST}

What impels the diarist to make his record? Boswell wrote, 'I am anxious that my life should tell' and eventually his diary became by transubstantiation life itself. 'I should live no more than I can record as one should not have more corn growing than one can get in', he wrote. He had no shame and the word 'discretion' was not in his vocabulary. 'Jamie, Jamie', said his outraged father, Lord Auchinleck, to him on one occasion, 'if you shat your breeches you would tell the world'. The diarist 


\section{Douglas Hubble}

knows that he himself is unique and he is right. He expects too that, however the world may deride him for his folly and weakness, such immortality as the written word may bestow will be his. His sins may be scarlet but his diary will be read.

Although but little limited by considerations of prestige and discretion the diarist must obey a code of rules as severe as those which bind men who enter the order of Ignatius Loyola. Roy Pascal in his book Design and Truth in Autobiography makes several just distinctions between biography, diary-keeping and autobiography. $\mathrm{He}$ writes: 'true autobiography can be written only by men and women pledged to their innermost selves'. Boswell's Life of Samuel Johnson and Moran's account of Winston Churchill contain much autobiographical writing and they reveal both Boswell and Moran as men 'pledged to their innermost selves'. The diarist's record must be as accurate as he can make it. He should have less than the normal man's desire to portray himself and his actions in as favourable a light as possible. History will inevitably smell out any self-inflationary intent. His industry must be unremitting and when other men put out the light and go to sleep, he must scribble through the night.

Beside this dedication to his self-imposed task he must have unusual gifts. $\mathrm{He}$ must be able to write in lively and dramatic fashion. He must select and interpret his material. He must look into the minds of his characters and examine their motives. He must study not only the dramatis personae, but he must depict the setting of the stage.

Boswell's eye may not have been as acute as his ear but certainly Moran's darting eye, so well pictured by Annigoni, missed very little. He records that he went into Churchill's bedroom the year after he had been rejected by the electorate (1946):

When I called at 28 Hyde Park Gate, to see if all was well for the trip to Florida, I noticed an open letter on the little table by the bed with the address in red lettering and in the big type of Buckingham Palace. Perhaps Winston followed my eyes; anyway he said:

'The King wants me to look through the speech for the State Banquet for the UNO delegates.' No. 10 had sent the speech to Buckingham Palace, who had sent it to Winston.

'Things seem pretty upside-down,' Winston grunted.

The diarist must have a subject and it is sufficient if his hero is himself. But if he can link his daily recording to a unique character and to great events then he knows that his work will receive the accolade of immortality.

\section{THE DIARISTS' ATTITUDE TO THEIR SUBJECTS}

Boswell was a hero-worshipper and inevitably his choice of heroes reflected the inadequacies in his own character of which he was all too conscious. Paoli in Corsica and Samuel Johnson in London were the bright candles whose beams attracted this erratic moth. ('My mind's great sun', Boswell flamboyantly called Samuel Johnson, as if to deride the feebleness of the candle metaphor which $I$ have used).

Moran recognized greatness when he saw it, but he was no hero-worshipper. His mind was too mature and too critical to ignore the defects of his subject. Moreover, the doctor sees man in his moments of weakness and strength, at times of frailty as well as of heroism. Given that Moran was impelled to write his book by the nature 


\section{Lord Moran and James Boswell}

of his gifts, by the content of his experience and by the uniqueness of his opportunity, he could not have written his book otherwise than he did.

His mind had long been fascinated by the pressures of war on the minds and bodies of men. As a young battalion medical officer in World War I this had been his daily preoccupation, and this bitter experience remained with him until he distilled it in his book The Anatomy of Courage published nearly thirty years later. Winston did not like this book - soldiers who did not do their duty ought to be shot-and Macmillan's, the publishers, refused to accept it for similar reasons. 'My dear Child', Moran wrote to his wife on being told of their refusal, 'I sometimes long for a more peaceful life without all these setbacks, but I see clearly that I was so made that these things will pursue me to the end . . . This book has become part of me, my apologia. It was a declaration that the little administrative, competitive life in which $I$ have been caught up was not really me ...'

For Moran his Winston Churchill is but a continuance of this testament and as we know the 'setbacks' have indeed pursued him to the end. It may well be that the attacks on this book were a surprise to him for he tells us that he had expected that Winston would approve of The Anatomy of Courage and indeed that he would write a preface for it. He may have similarly underestimated the adverse public reaction to his Winston Churchill. Many doctors and patients were revolted by the assumption that a doctor admitted to the confidences of the sick room could justifiably reveal these secrets. More were troubled that a national hero should be revealed in his weakness while the memory of their mourning for him was still fresh in their minds. 'Tomorrow, there would have been a time for such a word' but not when their 'finest hour', vividly associated with their dead hero, had been succeeded by decades of apparently undeserved weakness and difficulty. Moran, intent only on his great achievement, had considered these objections to publication but, as he relates in his preface, he had set them aside. So he made the choice to be pursued by these setbacks to the end.

\section{PROFESSIONAL ACHIEVEMENT AND AGREEABILITY}

There was a great difference in the professional standing of the two diarists. Boswell, when he visted Corsica in 1765, had not yet commenced practice at the Scottish bar. Pottle states that from 1766 to 1783 he followed the practice of the law in Edinburgh 'with complete regularity and a fair degreee of assiduity'. But his varied activities, including his writing and his love for life in London, did not allow him to achieve any great position in Scottish legal life and later he failed totally to break into professional practice at the English bar.

It was far otherwise with Charles Wilson. The year after he became Churchill's physician he was elected President of the Royal College of Physicians of London and remained so for nine years until 1950. He was at the top of his profession and it may be thought derisory to describe him as arriving 'in the middle of life' when he became Churchill's physician. But doctors rarely find themselves at the centre of great affairs when practising their profession. Once there they may, by the exercise of their personal qualities, become privileged observers of historic events and the intimate confidant of those directing great affairs. 


\section{Douglas Hubble}

Lord Ponsonby describes in his biography of his father, Sir Henry Ponsonby, how Dr. James Reid, the resident physician at Balmoral in Queen Victoria's day, achieved this. On his arrival he was informed that he would not be allowed to dine with the Household.

He was quite content with this arrangement which the Queen herself had laid down because, although she was fond of doctors, she still believed in the old convention that they should be put 'below the salt'. Very soon, however, members of the Household, on some occasions when the Household dinner was likely to be dull, found their way in to dine with Dr. Reid where they could be sure of pleasant entertainment. The Queen, of course, heard of this. 'I hear Dr. Reid has dinner parties!' So the restrictions on the resident physician broke down to the benefit of the Household dinner.

Lord Moran had James Reid's faculty of making himself agreeable in any company. The war leaders happily accepted him for his personal qualities and not only as Winston's doctor. So he was able to take risks in imposing his authority when it seemed necessary to him to do so. In Bermuda, on 15 January 1942, he wrote:

... the P.M. came up to me and, putting his arm through mine, said: 'We are returning by air. They are fixing up the details now. But we cannot all go in the flying-boat. I am sure you won't mind returning in the ship.'

I was completely taken by surprise, but as he spoke I knew I must not give way . . . I disengaged my arm and made for the house. I heard the P.M. say something soothingly but I took no notice. I found the Chiefs of Staff in a room in conference. I broke in without ceremony.

'I believe', I said, 'it has been decided to return by air, and that it is suggested the Prime Minister fly and I come by sea'.

I made it plain that I could not agree.

Boswell, too, was an equally attractive man. Sir Joshua Reynolds wrote to Bennet Langton on 12 September 1792, 'Mr. Burke says he (Boswell) is by much the most agreeable man he ever saw in all his life'. He was quickly admitted to the intimacies of Johnson's life. In two months he had made good his title to being regarded as a privileged friend by being taken to tea with Miss Williams, the blind poetess who lived with Johnson. At this time Boswell wrote, 'After we had again talked of my setting out for Holland, he said, 'I must see thee out of England: I will accompany you to Harwich".' So he escorted the young man to Harwich-an uncomfortable two-day journey-whence Boswell was setting out on his continental travels. As they said goodbye on the beach Boswell begged, 'I hope, Sir, you will not forget me in my absence' and Johnson replied 'No, Sir, it is more likely you should forget me than that I should forget you.'

These affectionate exchanges could be matched by several passages in Lord Moran's book. To take but one example. On 6 June 1955, the diary records:

He said he would like to give me one of his pictures. I was to choose three, so that there might be an alternative if my choice fell on a picture from which he could not bear to part. I had admired a painting of a lake with trees which faced me during luncheon.

'You must have that', he said.

When I left him his eyes filled with tears. 'I am touched with your kindness and devotion'.

THE DIARISTS' SOCIAL COURAGE

Boswell and Moran shared another essential quality, social courage. Both their 


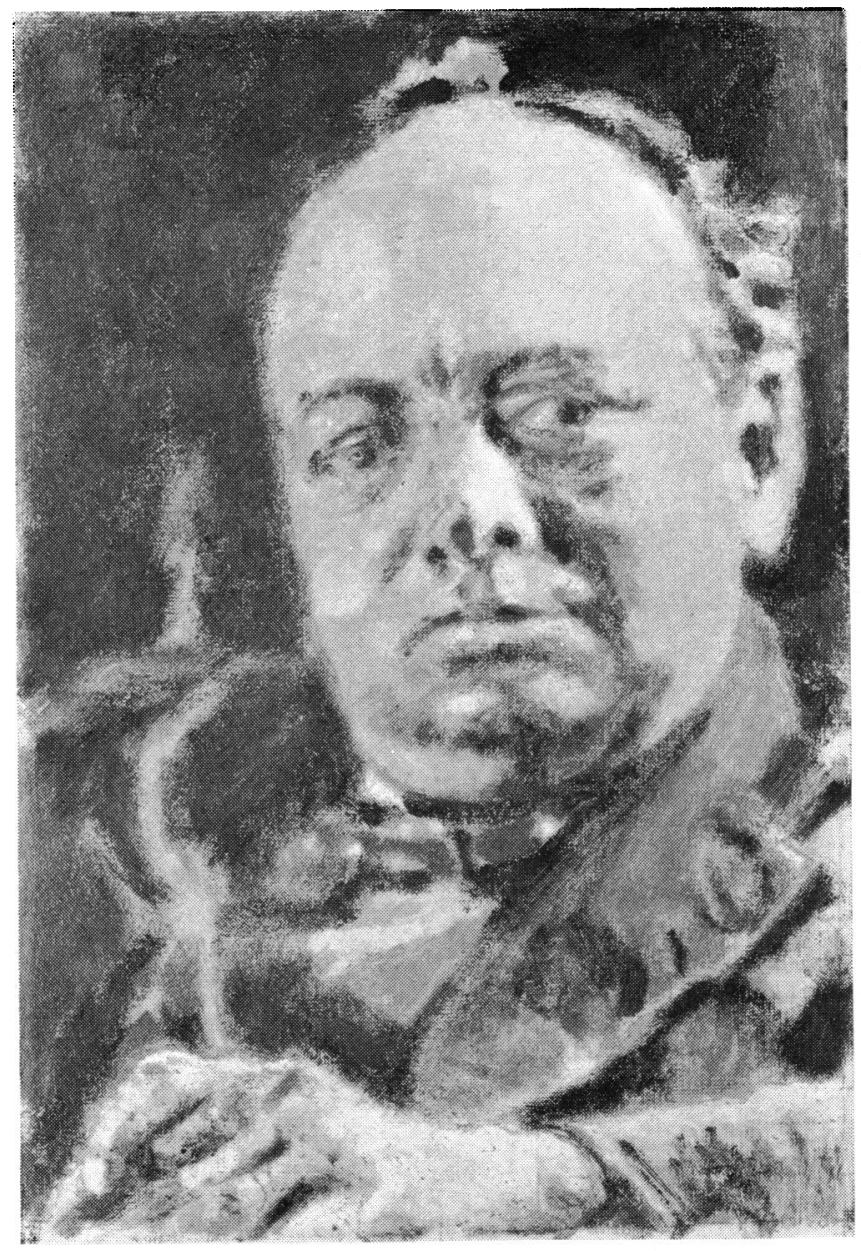

By courtesy of the National Portrait Gallery

Figure 1.

Winston Churchill, by Sickert (1927). 


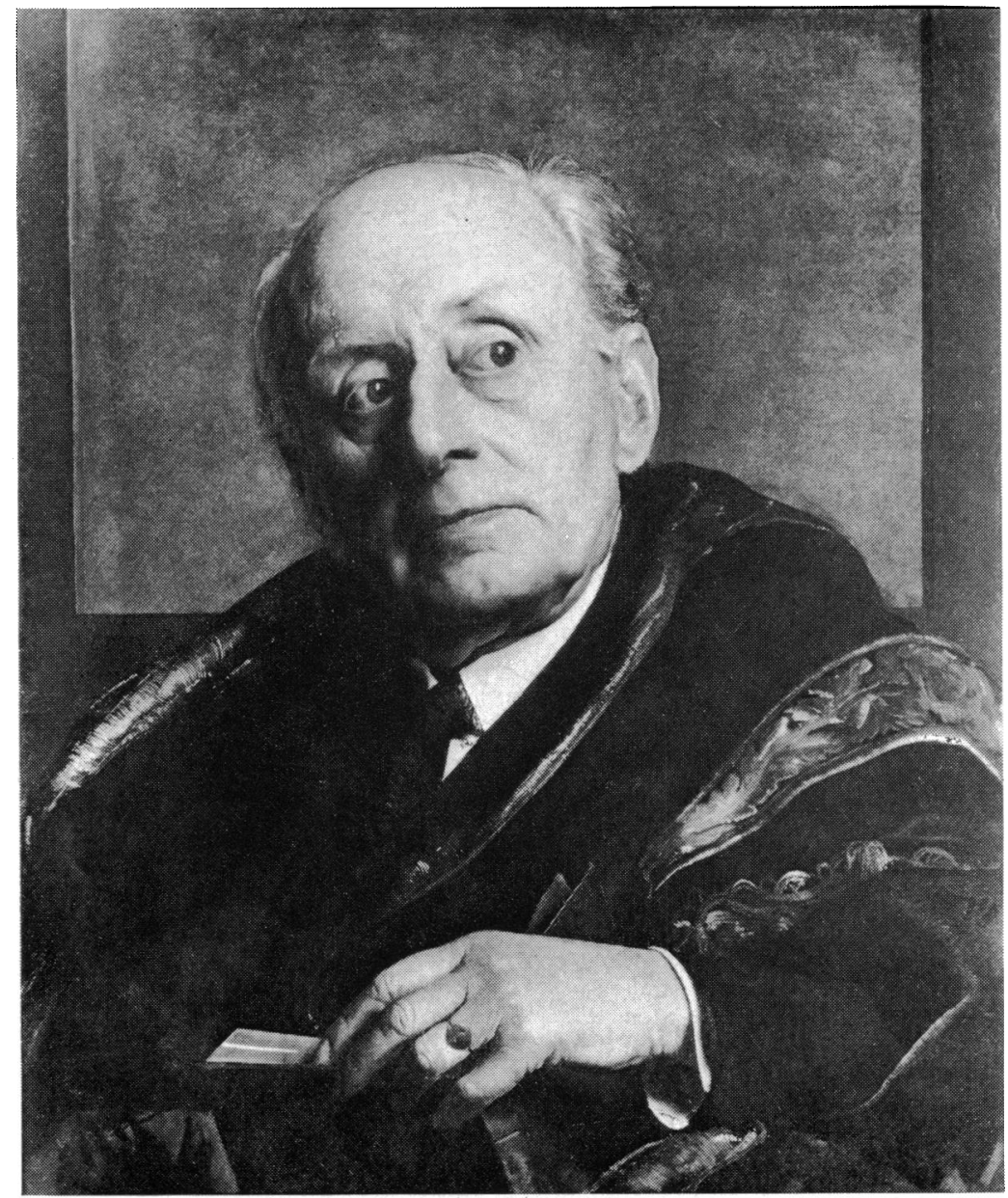

By courtesy of the Royal College of Physicians of London Figure 2.

Lord Moran, by Annigoni (1951). 


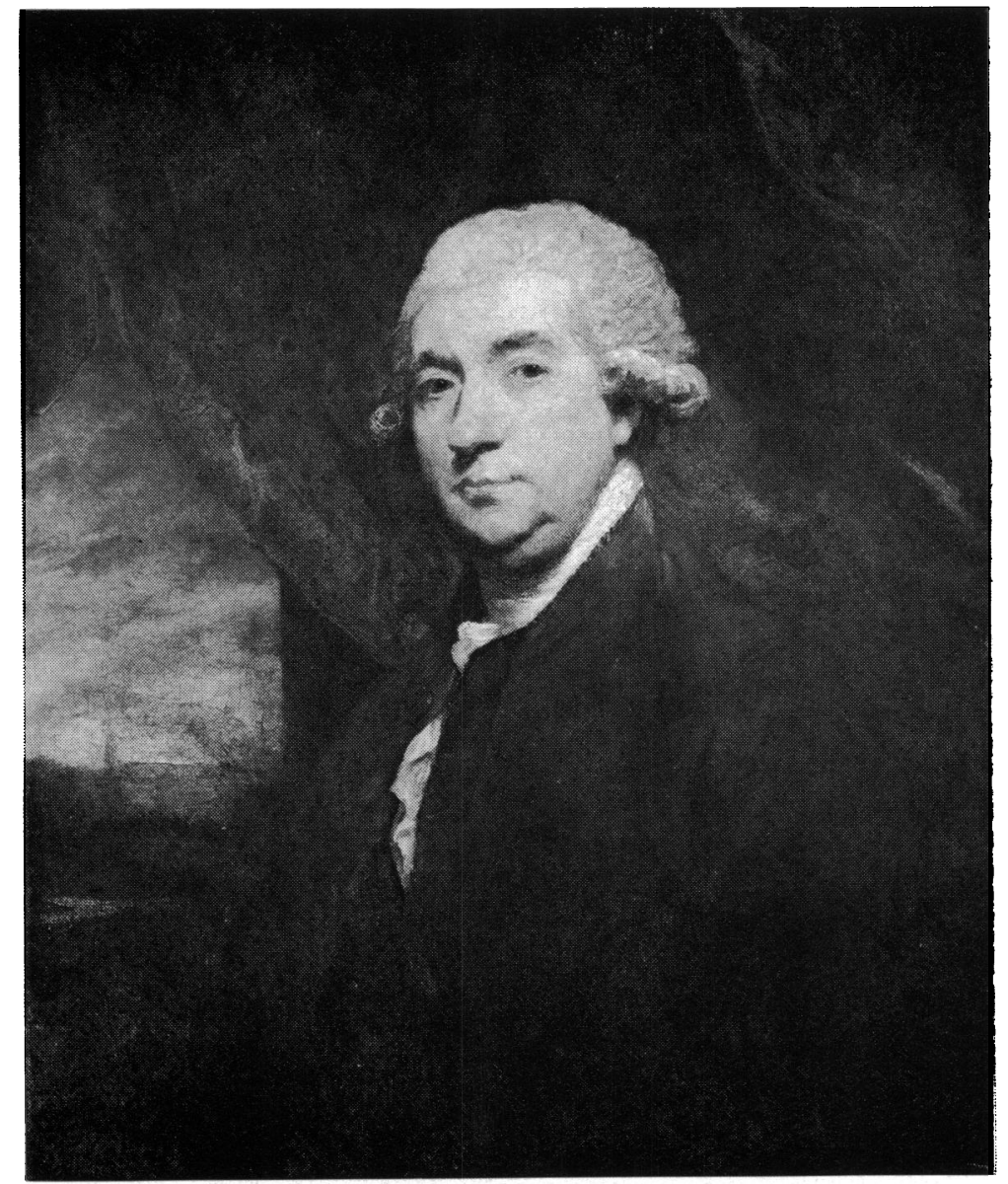

By courtesy of the National Portrait Gallery

Figure 3.

James Boswell, by Joshua Reynolds (1783). 


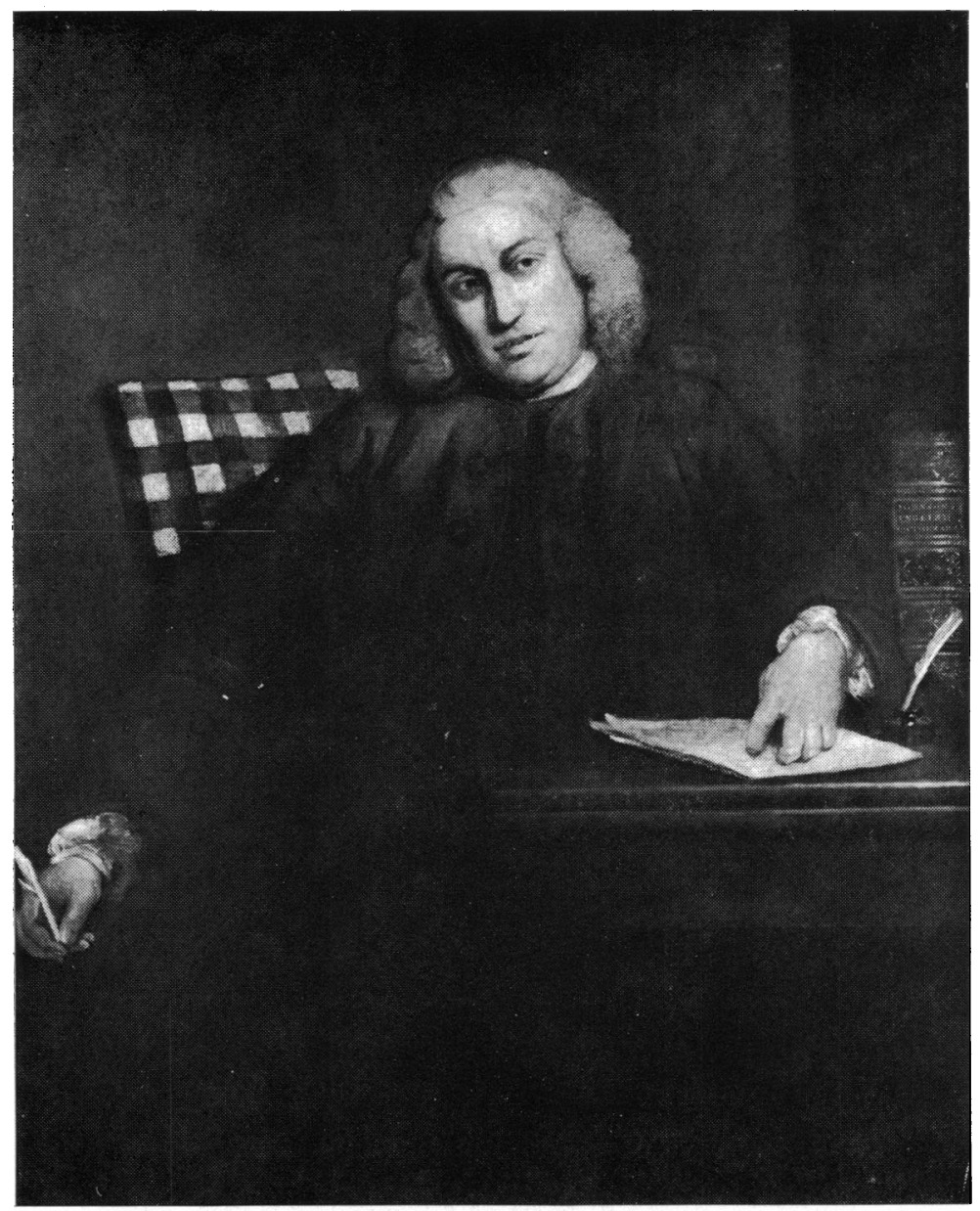

By courtesy of the National Portrait Gallery

Figure 4

Samuel Johnson, by Joshua Reynolds (1778). 


\section{Lord Moran and James Boswell}

subjects were irascible men and pugnacious. Both were conversationalists who, when in the mood, could terrify all but the most intrepid. Johnson 'talked for victory' and recalling the debate of a previous night Boswell said, 'Yes, you tossed and gored several persons'. Boswell, in order to put the 'Great Bear' through his paces, would unhesitatingly expose his flank. He was ready to behave like a fool if it served his great purpose. On one occasion when he had aroused Johnson's anger he wrote: 'I seemed to myself like the man who had put his head into the lion's mouth a great many times with perfect safety, but at last had it bit off'. He reports that another dialogue was brusquely concluded thus by Johnson, 'Sir, you have but two topics, yourself and me. I am sick of both'. You will observe the animal metaphors which were used to describe Samuel Johnson-bull, bear and lion.

Moran had the same social courage. He relates several conversations in which, in 'foolhardy' fashion, he opposed the great man's opinions till further resistance was of no avail. Let those who think that they might have lasted as long in Moran's place study carefully the record of 5 December 1943.

Last night at the Embassy we sat at the dinner table from 8 p.m. till 11.50 p.m. Mountbatten's eyes closed and opened spasmodically. I looked down the long table at the faces of the soldiers and sailors. They seemed only half awake. I was sorry for Winston: surely someone ought to show some interest in the drawn-out monologue. On the spur of the moment I blurted out: 'Do you remember Landor's lovely lines?'

Winston glared at me. He hates being interrupted. 'What are they?' he snorted.

I wanted to get under the table.

'What are they?' Winston shouted with growing impatience. I could think of no way of escape.

- "There are no fields of amaranth on this side of the grave; there are no voices, $O$ Rhodope, that are not soon mute, however tuneful; there is no name, with whatever emphasis of passionate love repeated, of which the echo is not faint at last."

I scampered over the lovely vowel sounds.

Winston (with great contempt): 'I call that pure defeatist stuff.'

I would not give in. I tried Milton: "While the still morn went out with sandals grey." ,

'He was on the wrong side in the Civil War,' Winston growled.

I gave it up.

After leaving the table we spent another hour and a half in the drawing-room. The servants talked in whispers. No one kept quite awake. At last, in a lull in the conversation, the P.M. was heard to make the same remark he had made three hours before. We were where we began.

The reason given by Moran for his brave intervention may be called in question, but the relevant conclusion is that he was, like Boswell, an active participant in the drama who preferred to be held in derision rather than sit in 'uncommunicating muteness' like the tired and lordly fish about him. So Churchill admired him, loved and trusted him. Six days later he was presiding with magisterial efficiency over the first attack of pneumonia.

\section{THE DIARISTS' CHARACTERS REVEALED}

Any biographer who essays biography by way of diary-keeping is certain to reveal as much of himself as he does of his subject. The diarist is by definition a man with an intense interest in himself. We now know more of James Boswell than of any man who has ever lived. Lord Moran is more discreet but he has not managed to exclude a great deal of information about himself as he writes about Winston Churchill.

Biographers and commentators have been, naively as it seems to me, astounded 


\section{Douglas Hubble}

at the complexities of Boswell's character. That a man should be at one and the same time a drunkard and an idealist, a whoremonger and a man of faith, a most agreeable companion and a squalid delinquent, a highly intelligent man who often spoke and behaved foolishly, an industrious man who was often idle, and a man of genius who sadly mismanaged his own affairs-these contradictions have bewildered observers with little insight into their own hearts and into the characters of other men. Macaulay, who would never have admitted himself to be at a loss in the interpretation of human personality, solved the Boswellian dilemma by refusing to see that it existed. For Macaulay, Boswell was a fool who wrote the finest biography in the English language solely by reason of this derided foolishness. Certainly it is easier to see Boswell in the round than it was a century ago. He remains a complicated character but if the publication of his journals has given us a spectacular account of his vices, they have also provided us with a new picture of his remarkable achievement.

If there are a dozen Boswells, there are at least six Morans and all of them can be defined in his book on Winston Churchill. There is Lord Moran the successful professional, Charles Wilson the humanist, the idealist, the literary artist, the devoted son, husband and father, and the man of ambition anxious, in Boswell's phrase, that his life should tell. Moran is not, like Boswell, a fragmented man, a man at war with himself. Of these characters depicted by our author only the idealist and the man of ambition came into conflict.

The humanist is best discovered in The Anatomy of Courage, but the literary artist is fully revealed in Winston Churchill. It is a remarkable book, not so great as Boswell's Johnson, because neither Churchill's intelligence nor his eloquence and wit are quite of the Johnsonian transcendent quality. But as a picture of a great man of action, first at the height of his achievement and then in 'slowly mounting decrepitude', it has no rival in English literature. It will be read as long as men are interested in Winston Churchill. As the years go by the topical question of whether a patient's confidence has been outraged by his physician's account of him both in his strength and in his weakness will no longer agitate the reader.

It is of Charles Wilson the idealist that the biography gives us a new account. I have already quoted a few phrases of the letter to his wife in which he writes of the rejection by Macmillan's of his book The Anatomy of Courage: 'It was a declaration that the little administrative, competitive life in which $I$ have been caught up was not really me'. This statement came from a man who had been for two years President of the Royal College of Physicians, a position for which he had urgently and successfully striven.

There is one more passage in the book which illustrates this other Charles Wilson. I quote it in full.

Tonight, when I was alone with Winston, to my consternation he said: 'I want you to tell me your story about the monastery [Monte Cassino]. No. I'd like to hear it. I have always tried to understand the point of austerity'-a broad grin appeared-'though I cannot claim that I have seriously practised it.'

This is the story I told him. It was before the First War, when I held the coveted office of Medical Registrar at St. Mary's Hospital. There was then only one registrar, and the occupant of the post was, as it were, on approval for two years. If he passed the scrutiny, he was generally elected to the next vacancy on the staff and became a physician to the hospital, a full-blooded consultant. 


\section{Lord Moran and James Boswell}

But, after a year in the office, I got it into my head-I was very young then-that some of my seniors were more concerned with their practices than with the students' training. It appeared a stuffy, material, and not very attractive existence, and I decided to send in my resignation. I did not give my reasons. It would sound priggish, I thought, if I tried to explain how I came to take such a suicidal step after all those years of apprenticeship.

As far as I can remember, I was not at all disconsolate that I had burnt my boats, irrevocably it seemed then. For some years my days had passed in the underground outpatient department of the hospital, lit even at noon by artificial light. I worked in a small room, like the inside cabin of a ship; it had no windows, and got very hot, and was full of microbes and of the sour smell of the human body. Then in the late afternoon, exchanging my white overall for a morning coat, I would don my top-hat and wind my way in and out of the vehicles and vans crowding the goods yard of the Great Western Railway, which then separated the hospital from the Harrow Road. For it was in that dreary street that I rented a single, shabby little room.

By coaching students for their final examinations I had been able to save a small sum of money, and this I planned to spend in travel-my resources would come to an end, I reckoned, in about a year.

It was in these circumstances that, in the spring of 1911, I found myself in Rome ready for adventure. One day I met a professor from Yale University, who told me he was going to Monte Cassino that afternoon. Whereupon I asked if I could go with him. From the wayside station we climbed in a creaking phaeton drawn by a dilapidated horse up what seemed like the side of a mountain. At length the driver, who had been encouraging his exhausted beast with curses and cracks of his whip, stopped at the gate of the monastery and rang the bell so violently that I felt abashed. A monk opened the door and spoke in Italian to the professor. He led us to a cell on the other side of the great stone building. That night I slept fitfully in my cell. Leaving my bed in the small hours, I wandered out into the long deserted passages, until I found myself in a chapel where a monk was at prayer. I do not suppose that I was a very serious youth, but I got down on my knees and prayed. I waited for a long time until he rose to his feet. He left the chapel, and I followed him. He led me to a great terrace or battlement which looked down a wooded precipice into a valley far below. He had come to the monastery from Belgium to carve the screen in the chapel. Quite simply he told me, when I asked him, why he had given up the world. And then we stood in silence drinking in the utter peace of the place as the night left us.

When I had come to the end of my story Winston seemed abstracted. At length he said:

'I suppose you believe in another life when we die?'

When I did not answer he pressed me:

'You have been trained in logic. Tell me why you believe such things.'

I had a feeling that he, too, wanted desperately to believe in something, but from what he said he did not find it easy.

'You would have made a good monk', he mused. There was a knock at the door. With an effort, Winston seemed to collect his thoughts. 'Tell me, Charles, did you never drink anything when you were with your battalion in France?'

\section{CONCLUSION}

In conclusion, we may review the qualities which these two diarists had in common and which were the major determinants in their achievement. I would put first the ability to write well and dramatically, and an impulse to put on record the day's happenings which was strong enough to overcome the drudgery of writing. Fate, and their ambition, gave them the opportunity to provide their unique narratives. Their personalities, of which I have emphasized the two characteristics of agreeability and social courage, made them active participants in the events they describe. Their achievement has a quality of greatness beyond the range of the general run of mankind.

\section{BIBLIOGRAPHY}

Balderston, Katherine C., Thraliana, 2nd ed., Oxford, Clarendon Press, 1951. 


\section{Douglas Hubble}

Boswell, JAmes, The Life of Samuel Johnson, ed. by L. F. Powell, Oxford, Clarendon Press, 1934.

Boswell, JAmes, Journal of a Tour to the Hebrides, London, Heinemann, 1936.

MORAN, LORD, The Anatomy of Courage, London, Constable, 1945.

MORAN, LORD, Winston Churchill. The Struggle for Survival (1940-1965), London, Constable, 1966.

Pascal, RoY, Design and Truth in Autobiography, London, Routledge \& Kegan Paul, 1960. Ponsonby, Arthur, Henry Ponsonby, London, Macmillan, 1942.

PotTle, Frederick A., James Boswell. The Earlier Years 1740-1769, London, Heinemann, 1966. 